\title{
Axial ocular dimensions and corneal astigmatism: The Kuala Pilah Cluster Cataract Study
}

Nur Hanis Yusri ${ }^{1}$, Syed Alsagoff Ahmed Daiyallah², Puspha Raman¹, Premala Devi Sivagurunathan $^{1}$, Khairul Husnaini Mohd Khalid ${ }^{1}$

${ }^{1}$ Department of Ophthalmology, Hospital Tuanku Ampuan Najihah Kuala Pilah, Negeri Sembilan, Malaysia; ${ }^{2}$ Department of Ophthalmology, Hospital Tampin, Negeri Sembilan, Malaysia

\section{Abstract}

Introduction: The Kuala Pilah Cluster Project involves Kuala Pilah Hospital as the lead hospital and the Jempol Hospital and Tampin Hospital as the district hospitals, serving as a single entity to provide ophthalmology services to the local population. Purpose: To evaluate the distribution of ocular biometric parameters and corneal astigmatism in patients presenting for cataract surgery within the Kuala Pilah Cluster Hospital System.

Study design and methods: A cross-sectional study conducted on 273 consecutive patients presented for cataract surgery between January and June 2017. Ocular biometry measurements, including axial length (AXL), lens thickness (LT), and anterior chamber depth (ACD) of each right eye were measured using immersion A-scan ultrasound. Keratometric $(K)$ readings were obtained via auto keratometer. Results: The mean values for AXL, ACD, and LT were $23.40 \pm 0.90 \mathrm{~mm}, 3.17 \pm 0.49 \mathrm{~mm}$, and $4.45 \pm 0.96 \mathrm{~mm}$, respectively. The average K-reading was $44.40 \pm 1.59 \mathrm{D}$, with a mean corneal astigmatism of $0.82 \pm 0.62 \mathrm{D}$. In this population, the females have significantly shorter AXL and ACD, but steeper $K$ compared to the males $(P<0.001)$. The local Malays have higher AXL and ACD values compared to the Chinese and Indians. A total of $35.5 \%$ patients exhibited a corneal astigmatism greater than $1 \mathrm{D}$. The magnitude of preoperative astigmatism positively correlated with age $(P<0.001)$. Conclusions: Ocular dimensions vary with gender and race in cataract patients from the Kuala Pilah cluster population. The probability of a patient requiring astigmatic

Correspondence: Dr. Puspha Raman, Department of Opthalmology, Hospital Tuanku Ampuan Najihah, Kuala Pilah, Negeri Sembilan, Malaysia.

E-mail:puspha@gmail.com 
correction increases with age. The average profile of ocular biometric data and corneal astigmatism may help local ophthalmologists to predict intraocular lens selections prior to cataract outreach projects.

Keywords: astigmatism, axial length, cataract, keratometry, ocular biometry

\section{Dimensi aksial dan astigmatisma kornea: Kajian Katarak Kluster Kuala Pilah}

\section{Abstrak}

Pengenalan: Projek Kluster Kuala Pilah melibatkan Hospital Kuala Pilah sebagai hospital utama, Hospital Jempol dan Hospital Tampin sebagai hospital daerah, yang berfungsi sebagai entiti tunggal untuk menyediakan perkhidmatan oftalmologi kepada penduduk setempat.

Tujuan: Untuk menilai liputan parameter biometrik okular dan astigmatisma kornea pada pesakit yang menjalani pembedahan katarak di Sistem Hospital Kluster Kuala Pilah.

Reka bentuk dan kaedah kajian: Kajian keratan rentas yang dilakukan pada 273 pesakit yang dijadualkan untuk pembedahan katarak antara Januari dan Jun 2017. Pengukuran biometri okular, termasuk panjang paksi (AXL), ketebalan lensa (LT), dan kedalaman ruang anterior (ACD) setiap mata kanan diukur dengan menggunakan ultrasound A-scan imersi. Bacaan Keratometrik (K) diperoleh melalui auto keratometer.

Keputusan: Nilai min bagi AXL, ACD, dan LT masing-masing adalah $23.40 \pm 0.90$ $\mathrm{mm}, 3.17 \pm 0.49 \mathrm{~mm}$, dan $4.45 \pm 0.96 \mathrm{~mm}$. Purata bacaan K adalah $44.40 \pm 1.59 \mathrm{D}$, dengan min astigmatisma kornea ialah $0.82 \pm 0.62 \mathrm{D}$. Dalam populasi ini, wanita didapati lebih pendek AXL dan ACD, tetapi K lebih curam berbanding dengan lelaki $(\mathrm{P}<0.001)$. Melayu tempatan mempunyai nilai AXL dan ACD yang lebih tinggi berbanding kaum Cina dan India. Sebanyak 35.5\% pesakit mempamerkan astigmatisma kornea yang lebih besar daripada $1 \mathrm{D}$. Besarnya astigmatisma pra-operasi positif berkorelasi dengan usia $(\mathrm{P}<0.001)$.

Kesimpulan: Dimensi ocular berbeza dengan jantina dan kaum pesakit katarak dari populasi kluster Kuala Pilah. Kebarangkalian pesakit yang memerlukan pembetulan astigmatik meningkat dengan usia. Profil data biometrik okular dan astigmatisma kornea boleh membantu pakar mata tempatan untuk meramalkan liputan kuasa kanta intraokular diperlukan sebelum projek pengesanan katarak luar bandar dijalankan. 
Kata kunci: astigmatisma, biometri okular, katarak, keratometri, panjang axial

\section{Introduction}

The Kuala Pilah Cluster Program is part of the Hospital Cluster Concept implemented by the Ministry of Health Malaysia. As one of the initiatives under the programme 'Transformasi Sistem Kesihatan' (Health Care Transformation System), this cluster system involves collaboration between government hospitals within the same state and geographical area. ${ }^{1}$ Together, the hospitals work as a single entity by sharing resources and facilities to provide specialist services to the local population. The Kuala Pilah Cluster Program comprises our centre, Tuanku Ampuan Najihah Kuala Pilah Hospital, as the lead hospital, along with two other district hospitals, Tampin Hospital and Jempol Hospital.

In 2014, the National Eye Survey II identified untreated cataract as the commonest cause of visual impairment in Malaysia, accounting for $58.6 \%$ of the total blindness. ${ }^{2}$ Accessible eye care with prompt cataract surgery is the key ophthalmology service provided by the Kuala Pilah Cluster Program as an initiative to combat cataract blindness in this region. Accurate measurements of ocular biometry and keratometry before cataract surgery are crucial for obtaining the precise power of intraocular lens in order to achieve good postoperative outcomes. Ocular biometric parameters are known to have racial variations. ${ }^{3,4}$ The Singapore Epidemiology of Eye Diseases (SEED) study reported ethnic variation in the ocular dimensions measured by IOLMaster (Carl Zeiss Meditec AG, Jena, Germany) among the three major ethnic groups - Chinese, Malays and Indians - in the urban area. ${ }^{5}$ However, there are no population-based studies available in Malaysia to compare demographics and ocular biometric trends in cataract patients from our multiethnic society and largely suburban dwellers with different socioeconomic background from our neighbouring country.

In this study, we aim to obtain an overview of the biometric characteristics across different gender and ethnic groups within the local population, and to determine the prevalence of corneal astigmatism before cataract surgery in the Kuala Pilah Cluster Hospital System.

\section{Materials and methods}

This is a prospective cross-sectional study conducted in the Kuala Pilah Cluster Hospital System. This study was approved by the institutional review board and adhered to the tenets of the Declaration of Helsinki. Consecutive patients who underwent cataract surgery between January and June 2017 were recruited. Exclusion criteria included history of refractive surgery, intraocular surgery, corneal 
disease and trauma. Ocular biometry measurements including axial length (AXL), lens thickness (LT), and anterior chamber depth (ACD) of each right eye were obtained using immersion A-scan ultrasound (Quantel Compact Touch A/P/B, Quantel Medical, Cournon d'Auvergne Cedex, France). Meanwhile, keratometry (K) readings were obtained via auto-kerato-refractometer (Autoref/keratometer ARK-1/ARK-1a/ARK-1s, Nidek, Japan). Keratometry (dioptres) was measured in flat and steep meridians. The $K$ value was calculated as the mean of these two meridians; Keratometric astigmatism calculated as the difference between these two meridians.

All statistical tests were performed using the IBM SPSS for Windows statistical software package (version 24.0; SPSS Inc., Chicago, Illinois, USA). Chi square was used for categorical variables, while the independent-sample t-test was used for continuous variables that are normally distributed and the Mann-Whitney $U$ test was used when the distribution was not normal. An ANOVA (analysis of variance) test was used to analyse different means among the variable group. Meanwhile, Pearson correlation was used to measure the strength of a linear association between two variables. $P$ values less than 0.05 were considered statistically significant.

\section{Results}

This study evaluated 273 eyes of 273 patients with a mean age of $67.99 \pm 8.74$ years. The majority of the patients were male $(55.7 \%)$ and ethnic background showed predominantly Malays ( $57.1 \%)$, followed by Chinese (28.6\%), Indians (13.6\%), and others (0.7\%).

The mean AL was $23.40 \pm 0.90 \mathrm{~mm}$. The mean values for ACD and LT were $3.17 \pm$ $0.49 \mathrm{~mm}$ and $4.45 \pm 0.96 \mathrm{~mm}$, respectively. The average K-reading was $44.40 \pm 1.59$ $\mathrm{D}$, with a mean corneal astigmatism of $0.82 \pm 0.62 \mathrm{D}$. Figure 1 shows the distribution of corneal astigmatism in the study population. A total of $35.5 \%$ patients exhibited a corneal astigmatism greater than $1 \mathrm{D}$.

In this population, females have significantly shorter AL and ACD than males ( $23.17 \pm 0.92 \mathrm{~mm}$ and $3.03 \pm 0.45 \mathrm{~mm}$ respectively, $\mathrm{p}<0.001)$. However, females have steeper $\mathrm{K}$ compared to males $(44.83 \pm 1.48 \mathrm{D}, \mathrm{p}<0.001)$ (Table 1$)$. In terms of ethnicity, Malays have significantly longer AL $(23.48 \pm 0.87 \mathrm{~mm}, p=0.027)$ and ACD $(3.26 \pm 0.48 \mathrm{~mm}, \mathrm{p}<0.0001)$, whereas Indians have greater LT $(4.66 \pm 0.84, p=0.003)$ (Table 2).

Pearson correlation analysis showed that lens thickness increases with age $(p=0.046)$, while ACD decreases with age $(p<0.0001)$. Moreover, the magnitude of preoperative astigmatism also positively correlates with age $(p<0.001)$. There was no significant association between axial length and age (Fig. 2). 


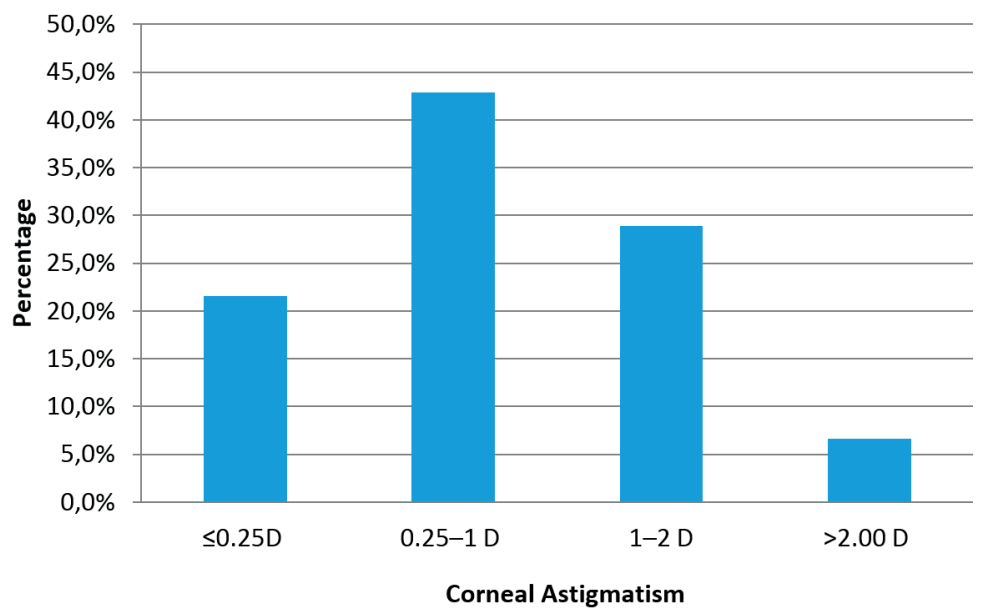

Fig. 1. Distribution of corneal astigmatism in the study population.

a

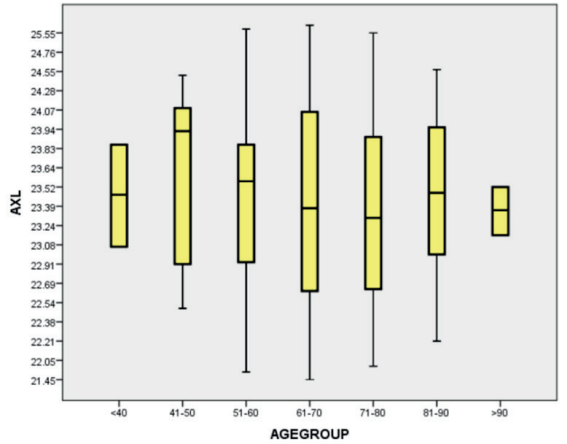

C

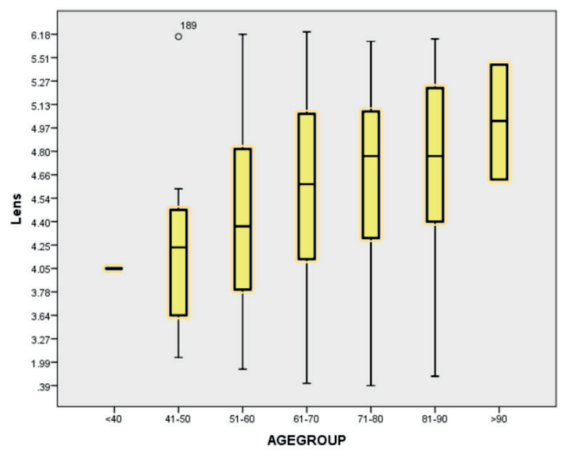

b

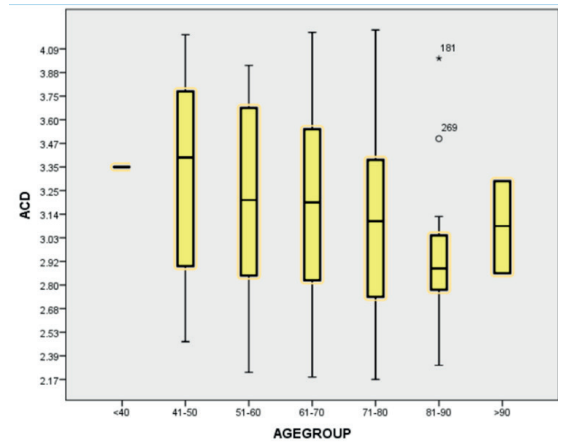

d

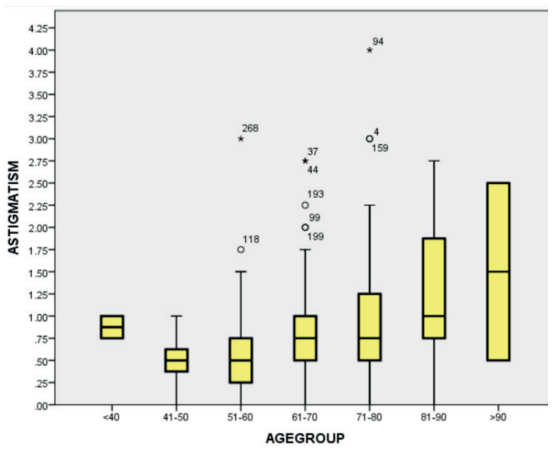

Fig. 2. Box-plot showing correlation between age group and $A L(a), A C D(b), \operatorname{LT}(c)$, and corneal astigmatism $(d)$. 
Table 1. Ocular biometry distribution by gender

\begin{tabular}{|l|l|l|l|l|}
\hline Variables & $\begin{array}{l}\text { Total } \\
(\mathbf{n}=\mathbf{2 7 3})\end{array}$ & $\begin{array}{l}\text { Male } \\
(\mathbf{n}=\mathbf{1 5 2})\end{array}$ & $\begin{array}{l}\text { Female } \\
(\mathbf{n}=\mathbf{1 2 1})\end{array}$ & P value \\
\hline AXL, mm & $23.40 \pm 0.90$ & $\mathbf{2 3 . 5 8} \pm \mathbf{0 . 8 3}$ & $23.17 \pm 0.92$ & $<0.0001$ \\
\hline ACD, mm & $3.17 \pm 0.49$ & $\mathbf{3 . 2 8} \pm \mathbf{0 . 4 9}$ & $3.03 \pm 0.45$ & $<0.0001$ \\
\hline LT, mm & $4.45 \pm 0.96$ & $4.42 \pm 0.99$ & $4.47 \pm 0.95$ & 0.661 \\
\hline Average K, D & $44.41 \pm 1.59$ & $44.07 \pm 1.59$ & $\mathbf{4 4 . 8 3} \pm \mathbf{1 . 4 8}$ & $<0.0001$ \\
\hline Astigmatism, D & $0.82 \pm 0.62$ & $0.86 \pm 0.67$ & $0.77 \pm 0.56$ & 0.203 \\
\hline
\end{tabular}

ACD: anterior chamber depth; AXL: axial length; LT: lens thickness; D: dioptre AXL, ACD, LT: independent t-test; average K, astigmatism: Mann-Whitney U test p-values $<0.05$ considered significant

Table 2. Ocular biometry distribution by ethnicity

\begin{tabular}{|l|l|l|l|l|l|}
\hline Variables & $\begin{array}{l}\text { Total } \\
(\mathbf{n}=\mathbf{2 7 3})\end{array}$ & $\begin{array}{l}\text { Malay } \\
(\mathbf{n}=\mathbf{1 5 6})\end{array}$ & $\begin{array}{l}\text { Chinese } \\
(\mathbf{n}=\mathbf{7 8})\end{array}$ & $\begin{array}{l}\text { Indian } \\
(\mathbf{n}=\mathbf{3 7})\end{array}$ & $\mathbf{p}$ \\
\hline AXL, mm & $23.40 \pm 0.90$ & $\begin{array}{l}\mathbf{2 3 . 4 8} \\
\mathbf{0 . 8 7}\end{array}$ & $23.41 \pm 0.93$ & $23.00 \pm 0.84$ & 0.027 \\
\hline ACD, mm & $3.17 \pm 0.49$ & $\mathbf{3 . 2 6} \pm \mathbf{0 . 4 8}$ & $3.03 \pm 0.44$ & $3.01 \pm 0.48$ & $<0.0001$ \\
\hline LT, mm & $4.44 \pm 0.97$ & $4.38 \pm 0.96$ & $4.52 \pm 0.94$ & $\mathbf{4 . 6 6} \pm \mathbf{0 . 8 4}$ & 0.003 \\
\hline Average K, D & $44.41 \pm 1.59$ & $44.30 \pm 1.50$ & $44.50 \pm 1.53$ & $44.71 \pm 2.05$ & 0.454 \\
\hline Astigmatism, D & $0.82 \pm 0.62$ & $0.78 \pm 0.59$ & $0.92 \pm 0.60$ & $0.77 \pm 0.76$ & 0.405 \\
\hline
\end{tabular}

ACD: anterior chamber depth; AXL: axial length; LT: lens thickness; D: dioptre ANOVA test used to calculate difference between groups $p$-values $<0.05$ considered significant 


\section{Discussion}

Our study reports cross-sectional data on demographic and ocular biometric characteristics for a multiethnic population in the Kuala Pilah Cluster Hospital Program presenting for cataract surgery. Patients presenting for cataract surgery in Kuala Pilah were predominantly elderly, male, of Malay ethnicity, and with corneal astigmatism less than one D. Although there are similar studies conducted in other South East Asian countries, to our knowledge, our study is the first to provide normative data for ocular dimensions in Malaysian population.

The ocular dimensions of the eye have been known to be influenced by ethnicity and racial factors. Table 3 summarises the ethnic group differences between our population and other major population-based studies. The mean AL of our population is $23.40 \mathrm{~mm}$, shorter than Singaporeans $(23.88 \mathrm{~mm}),{ }^{5}$ longer than Burmese $(23.14 \mathrm{~mm}),{ }^{6}$ Chinese $(23.11 \mathrm{~mm}),{ }^{7}$ Mongolian $^{8}(23.13 \mathrm{~mm})$, and Auckland Caucasians $(23.14 \mathrm{~mm}),{ }^{9}$ but similar to the Latinos $(23.38 \mathrm{~mm}) .{ }^{10}$ It is worthwhile to dissect our findings by ethnic groups, where we found the Malays have significantly longer AXL and deeper ACD compared to the local Chinese and Indians.

Table 3. Comparison of demographic features between the present study and other published studies

\begin{tabular}{|c|c|c|c|c|}
\hline & Present study & SINDI $^{12}$ & TPS $^{13}$ & SIMES ${ }^{11}$ \\
\hline Location & Kuala Pilah cluster & $\begin{array}{l}\text { Adult Indian } \\
\text { Singapore }\end{array}$ & $\begin{array}{l}\text { Adult Chinese- } \\
\text { Singapore }\end{array}$ & $\begin{array}{l}\text { Adult Malay } \\
\text { Singapore }\end{array}$ \\
\hline Eyes/patients & $273 / 273$ & $2785 / 2785$ & $1004 / 1004$ & $2788 / 2788$ \\
\hline Age (y) Mean & $67.99 \pm 8.74$ & $57.8 \pm 10.1$ & NA & 57.3 \\
\hline Range & 28,94 & 40,83 & 40,81 & 40,80 \\
\hline Male/Female & $152 / 121$ & $1406 / 1379$ & $457 / 547$ & $1333 / 1455$ \\
\hline $\begin{array}{l}\text { AXL (mm) } \\
\text { All } \\
\text { Male } \\
\text { Female }\end{array}$ & $\begin{array}{l}23.40 \pm 0.90 \\
23.58 \pm 0.83 \\
23.17 \pm 0.92\end{array}$ & $\begin{array}{l}23.45 \pm 1.10 \\
23.68 \pm 1.06 \\
23.23 \pm 1.10\end{array}$ & $\begin{array}{l}23.23 \pm 1.17 \\
23.54 \pm 1.10 \\
22.98 \pm 1.16\end{array}$ & $\begin{array}{l}23.55 \\
23.75 \\
23.38\end{array}$ \\
\hline $\begin{array}{l}\text { ACD }(\mathrm{mm}) \\
\text { All } \\
\text { Male } \\
\text { Female }\end{array}$ & $\begin{array}{l}3.17 \pm 0.49 \\
3.28 \pm 0.49 \\
3.03 \pm 0.45\end{array}$ & $\begin{array}{l}3.15 \pm 0.36 \\
3.19 \pm 0.36 \\
3.10 \pm 0.35\end{array}$ & $\begin{array}{l}2.90 \pm 0.44 \\
2.99 \pm 0.45 \\
2.81 \pm 0.47\end{array}$ & $\begin{array}{l}3.08 \\
3.13 \\
3.03 \\
\end{array}$ \\
\hline $\begin{array}{l}\text { Keratometry } \\
\text { Male } \\
\text { Female }\end{array}$ & $\begin{array}{l}\text { K-reading } \\
\text { (D) } \\
44.07 \pm 1.59 \\
44.83 \pm 1.48\end{array}$ & $\begin{array}{l}\text { K-reading } \\
\text { (D) } \\
43.88 \\
44.63\end{array}$ & $\begin{array}{l}\text { Corneal radius } \\
(\mathrm{mm}) \\
7.73 \pm 0.29 \\
7.59 \pm 0.24\end{array}$ & $\begin{array}{l}\text { Corneal radius } \\
(\mathrm{mm}) \\
7.71 \\
7.59\end{array}$ \\
\hline
\end{tabular}

ACD: anterior chamber depth; AL: axial length; D: dioptre 
Similar findings were shown in population-based studies in Singapore, namely, the Singapore Malay Eye Study (SIMES), ${ }^{11}$ Singapore Indian Eye Study (SiNDI), ${ }^{12}$ and Tanjong Pagar Survey (Singapore Chinese). ${ }^{13}$ It is interesting to note that Chinese adults among our local population have longer $A X L$ and deeper ACD compared to the Singapore Chinese ${ }^{13}$ and Liwan Chinese. ${ }^{7}$ Meanwhile, Indians among our local population have shorter AXL than the Singaporeans, but much longer than the Indians from Central India $(22.6 \mathrm{~mm})$. These findings are in line with emerging evidence that biometric parameters are influenced by anthropometric measurements and socioeconomic backgrounds, rather than by genetic ancestry. ${ }^{14-17}$ Urbanisation is believed to contribute to the elongation of AXL by increasing the demand of near-sighted work and less exposure to sunlight. ${ }^{18,19}$

In this population, females were shown to have significantly shorter AXL and ACD. Other ocular biometry studies have produced similar results. ${ }^{7,8,10,15}$ This shows that ocular dimensions correlate well with human anthropometrics, where females have smaller body stature compared to males. The shorter AXL and ACD in females contribute towards a shallower ACD, predicting a higher risk for angle-closure glaucoma. LT was shown to increase with age; conversely, ACD had a negative correlation with age. Naturally, with the occurrence of cataract, the LT increases, thus reducing the ACD. Cataract surgery is proven to significantly deepen the anterior chamber. ${ }^{20}$ We postulate that early cataract surgery in older women from our local population may reduce the incidence of angle-closure glaucoma.

The results of this study also show the positive correlation between preoperative corneal astigmatism $(P<0.001)$ with age. The prevalence of corneal astigmatism and its association with age have been well documented in the literature. ${ }^{21-24} \mathrm{Hayashi}$ et $a l$. has shown that irregular corneal astigmatism tends to increase from middle to older age groups regardless of cataract surgery..$^{23}$ It is hypothesised that changes in upper lid tension and corneal degeneration contribute to this changes. ${ }^{25}$ We have found that $35.5 \%$ of the cataract patients have a corneal astigmatism greater than $1 \mathrm{D}$. This figure is almost identical to that of Hoffmann et al. from Germany, who reported $36 \%{ }^{26}$ and Ferrer-Blasco from Spain (34.8\%). ${ }^{27}$ Oher major studies have shown a slightly higher percentage, with De Bernardo et al. from Italy reporting $41.4 \%{ }^{28}$ and Wakefield et al. from England reporting 44.2\%. ${ }^{22}$ Patients with more than $1 \mathrm{D}$ of astigmatism should be considered for surgical correction during surgery for better postoperative visual outcomes and spectacle independence.

The limitation of our study is that this is a hospital-based study, and therefore more susceptible to selection bias. Population-based data with cluster samples will provide a more accurate illustration of normative data in Malaysia. We also recommend for our National Eye Registry for Cataract Surgery to include ocular biometry data to pave ways for future studies on ocular anatomical differences.

In conclusion, in the Kuala Pilah Cluster population, females have significantly shorter AL, ACD, and steeper K compared to males. Moreover, Malays among the local population have higher AXL and ACD values compared to Chinese and Indians 
in the same population. This study also shows that the probability of a patient requiring astigmatic correction increases with age. The information regarding the average profile of ocular biometric data and corneal astigmatism may help local ophthalmologists to select intraocular lens more precisely prior to cataract outreach projects within this population.

\section{Acknowledgments}

We would like to thank the Director General of Health Malaysia for his permission to publish this article.

\section{References}

1. Noriah Bidin Sewpe, Nik Nur Eliza Mohamed, Nor Izzah Ahmad Shauki. Cost Effectiveness Analysis of Cluster Hospital Pilot Projects in Transforming The Healthcare Service in Malaysia. Institute of Health Management; 2016.

2. Chew FL, Salowi MA, Mustari Z, Husni MA, Hussein E, Adnan TH, et al. Estimates of visual impairment and its causes from the National Eye Survey in Malaysia (NESII). PloS One. 2018;13(6):e0198799.

3. Wang D, Amoozgar B, Porco T, Wang Z, Lin SC. Ethnic differences in lens parameters measured by ocular biometry in a cataract surgery population. PloS One. 2017;12(6):e0179836-e.

4. Niu Z, Li J, Zhong H, et al. Large variations in ocular dimensions in a multiethnic population with similar genetic background. Sci Rep. 2016;6:22931.

5. Pan C-W, Zheng Y-F, Anuar AR, et al. Prevalence of Refractive Errors in a Multiethnic Asian Population: The Singapore Epidemiology of Eye Disease Study. Invest Ophthalmol Vis Sci. 2013;54(4):2590-2598.

6. Warrier S, Wu HM, Newland HS, Muecke J, Selva D, Aung T, et al. Ocular biometry and determinants of refractive error in rural Myanmar: the Meiktila Eye Study. Br J Ophthalmol. 2008;92(12):1591-1594.

7. He M, Huang W, Li Y, Zheng Y, Yin Q, Foster PJ. Refractive Error and Biometry in Older Chinese Adults: The Liwan Eye Study. Invest Ophthalmol Vis Sci. 2009;50(11):5130-5136.

8. Wickremasinghe S, Foster PJ, Uranchimeg D, et al. Ocular Biometry and Refraction in Mongolian Adults. Invest Ophthalmol Vis Sci. 2004;45(3):776-783.

9. Riley AF, Malik TY, Grupcheva CN, Fisk MJ, Craig JP, McGhee CN. The Auckland cataract study: co-morbidity, surgical techniques, and clinical outcomes in a public hospital service. Br J Ophthalmol. 2002;86(2):185-190.

10. Shufelt C, Fraser-Bell S, Ying-Lai M, Torres M, Varma R. Refractive error, ocular biometry, and lens opalescence in an adult population: the Los Angeles Latino Eye Study. Invest Ophthalmol Vis Sci. 2005;46(12):4450-4460.

11. Lim LS, Saw S-M, Jeganathan VSE, et al. Distribution and determinants of ocular biometric parameters in an Asian population: the Singapore Malay eye study. Invest Ophthalmol Vis Sci. 2010;51(1):103109. 
12. Pan C-W, Wong T-Y, Chang L, et al. Ocular biometry in an urban Indian population: the Singapore Indian Eye Study (SINDI). Invest Ophthalmol Vis Sci. 2011;52(9):6636-6642.

13. Wong TY, Foster PJ, Ng TP, Tielsch JM, Johnson GJ, Seah SK. Variations in ocular biometry in an adult Chinese population in Singapore: the Tanjong Pagar Survey. Invest Ophthalmol Vis Sci. 2001;42(1):73-80.

14. Wong T, Foster P, Johnson G, Seah S. Education, socioeconomic status, and ocular dimensions in Chinese adults: the Tanjong Pagar Survey. Br J Ophthalmol. 2002;86(9):963-968.

15. Wong TY, Foster PJ, Johnson GJ, Klein BE, Seah SK. The relationship between ocular dimensions and refraction with adult stature: the Tanjong Pagar Survey. Invest Ophthalmol Vis Sci. 2001;42(6):12371242.

16. Lee KE, Klein BE, Klein R, Quandt Z, Wong TY. Association of age, stature, and education with ocular dimensions in an older white population. Arch Ophthalmol. 2009;127(1):88-93.

17. Hilkert SM, Parness-Yossifon R, Mets-Halgrimson R, Mets MB. Ocular biometry and determinants of refractive error in a founder population of European ancestry. Ophthalmic Genet. 2018;39(1):11-16.

18. Morgan IG, Ohno-Matsui K, Saw SM. Myopia. Lancet (London, England). 2012;379(9827):1739-1748.

19. Smith EL 3rd, Hung LF, Arumugam B. Visual regulation of refractive development: insights from animal studies. Eye (London, England). 2014;28(2):180-188.

20. Lee RY, Kasuga T, Cui QN, Huang G, Wang SY, Lin SC. Ethnic differences in intraocular pressure reduction and changes in anterior segment biometric parameters following cataract surgery by phacoemulsification. Clin Exp Ophthalmol. 2013;41(5):442-449.

21. KhabazKhoob M, Hashemi H, Yazdani K, Mehravaran S, Yekta A, Fotouhi A. Keratometry measurements, corneal astigmatism and irregularity in a normal population: the Tehran Eye Study. Ophthalmic Physiol Opt. 2010;30(6):800-805.

22. Wakefield OC, Annoh R, Nanavaty M. Relationship between age, corneal astigmatism, and ocular dimensions with reference to astigmatism in eyes undergoing routine cataract surgery. Eye. 2016;30(4):562.

23. Hayashi K, Kawahara S, Manabe S-i, Hirata A. Changes in irregular corneal astigmatism with age in eyes with and without cataract surgery. Invest Ophthalmol Vis Sci. 2015;56(13):7988-7998.

24. Ueno Y, Hiraoka T, Beheregaray S, Miyazaki M, Ito M, Oshika T. Age-related changes in anterior, posterior, and total corneal astigmatism. J Refract Surg. 2014;30(3):192-7.

25. Hayashi K, Hayashi H, Hayashi F. Topographic analysis of the changes in corneal shape due to aging. Cornea. 1995;14(5):527-532.

26. Hoffmann PC, Hütz WW. Analysis of biometry and prevalence data for corneal astigmatism in 23,239 eyes. J Cataract Refract Surg. 2010;36(9):1479-1485.

27. Ferrer-Blasco T, Montes-Mico R, Peixoto-de-Matos SC, Gonzalez-Meijome JM, Cervino A. Prevalence of corneal astigmatism before cataract surgery. J Cataract Refract Surg. 2009;35(1):70-75.

28. De Bernardo M, Zeppa L, Cennamo M, laccarino S, Zeppa L, Rosa N. Prevalence of corneal astigmatism before cataract surgery in Caucasian patients. Eur J Ophthalmol. 2014;24(4):494-500. 